\title{
A novel chemotherapeutic sensitivity- testing system based on collagen gel droplet embedded 3D-culture methods for hepatocellular carcinoma
}

Jun Hou ${ }^{1 \dagger}$, Zhixian Hong ${ }^{2 \dagger}$, Fan Feng ${ }^{1 \dagger}$, Yantao Chai ${ }^{1}$, Yunkai Zhang ${ }^{1}$, Qiyu Jiang ${ }^{1}$, Yan Hu' ${ }^{1}$, Shunquan Wu ${ }^{1}$, Yingsong $\mathrm{Wu}^{3}$, Xunian $\mathrm{GaO}^{4}$, Qiong $\mathrm{Chen}^{3}$, Yong Wan ${ }^{3}$, Jingfeng $\mathrm{Bi}^{\mathrm{i}^{* *}}$ and Zheng Zhang ${ }^{{ }^{*}}$

\begin{abstract}
Background: Patients suffering from advanced stage hepatocellular carcinoma (HCC) often exhibit a poor prognosis or dismal clinical outcomes due to ineffective chemotherapy or a multi-drug resistance (MDR) process. Thus, it is urgent to develop a new chemotherapeutic sensitivity testing system for HCC treatment. The presence study investigated the potential application of a novel chemotherapeutic sensitivity-testing system based on a collagen gel droplet embedded 3D-culture system (CD-DST).
\end{abstract}

Methods: Primary cells were separating from surgical resection specimens and then tested by CD-DST. To identify whether HCC cell lines or cells separating from clinical specimens contain MDR features, the cells were treated with an $\mathcal{C}_{50}$ (half maximal inhibitory concentration) or $\mathcal{I}_{\max }$ (maximal inhibitory concentration) concentration of antitumor agents, e.g., 5-furuolouracil (5-FU), paclitaxel (PAC), cisplatin (CDDP), epirubicin (EPI), or oxaliplatin (L-OHP), and the inhibitory rates (IRs) were calculated.

Results: HepG2 cells were sensitive to 5 -FU, PAC, CDDP, EPI, or L-OHP; the $/ C_{50}$ value is $0.83 \pm 0.45 \mu \mathrm{g} / \mathrm{ml}, 0.03 \pm 0$. $02 \mu \mathrm{g} / \mathrm{ml}, 1.15 \pm 0.75 \mu \mathrm{g} / \mathrm{ml}, 0.09 \pm 0.03 \mu \mathrm{g} / \mathrm{ml}$, or $1.76 \pm 0.44 \mu \mathrm{g} / \mathrm{ml}$, respectively. Only eight (8/26), nine (9/26), or five (5/26) patients were sensitive to the $I_{\max }$ concentration of CDDP, EPI, or L-OHP; whereas only three $(3 / 26)$, four (4/26), or two $(2 / 26)$ patients were sensitive to the $I_{50}$ concentration of CDDP, EPI, or L-OHP. No patients were sensitive to 5-FU or PAC.

Conclusions: The in vitro drug sensitivity exanimation revealed the MDR features of HCC and examined the sensitivity of HCC cells from clinical specimens to anti-tumor agents. CD-DST may be a useful method to predict the potential clinical benefits of anticancer agents for HCC patients.

Keywords: Hepatocellular carcinoma, Multi-drug resistance, Collagen gel droplet embedded 3D-culture system, Chemotherapies

\footnotetext{
*Correspondence: 123bjf@163.com; zhangzheng1975@aliyun.com

${ }^{\dagger}$ Equal contributors

${ }^{1}$ Research Center for Clinical and Translational Medicine, the 302nd Hospital

of Chinese PLA, Beijing 100039, People's Republic of China

Full list of author information is available at the end of the article
} 


\section{Background}

$\mathrm{HCC}$ is currently one of the most common causes of cancer-related deaths in China and the Asian-Pacific region [1-3]. In China, there are 466,100 new cases, and 422,100 deaths occur per year [2-5]. Although hepatic resection may be the first choice of treatment, only a small proportion (10-15\%) of patients are suitable [6, 7]. Patients often suffer from advanced stage HCC upon their initial diagnosis and exhibit poor prognosis due to multi-drug resistance (MDR) features [8-10]. Thus, it is urgent and significant to develop a new chemotherapeutic sensitivity testing system for HCC treatment. Previously, the sensitivity of HCC cells to anti-tumor agents is often tested via MTT (3- $(4,5-$ dimethyl-2-thiazolyl)-2, 5-diphenyl-2-H-tetrazolium bromide) assays or SRB (Sulforhodamine B) assays based on the two-dimensional (2-D) monolayer culture [11]. However, cancer cells in solid tumors grow in a three-dimensional (3-D) pattern [12]. In this respect, an in vitro 2-D cell cultural model is limited in evaluating the clinical efficacy of chemotherapies [13]. Therefore, it is urgent to establish an in vitro model reflecting the 3-D culture of tumor cells.

CD-DST is a mature test in which primary-culture cells are embedded in collagen droplets [11-16].

Table 1 Baseline characteristics of patients

\begin{tabular}{|c|c|}
\hline Clinical features & Values (number (\%)) \\
\hline Age(yr) & $51.3 \pm 7.4$ \\
\hline \multicolumn{2}{|l|}{ Gender } \\
\hline Male & $20(76.92 \%)$ \\
\hline Female & $6(23.08 \%)$ \\
\hline \multicolumn{2}{|l|}{ Aetiology } \\
\hline Hbs-Ag positive & $23(88.46 \%)$ \\
\hline HCV-Ab positive & 3 (11.54\%) \\
\hline \multicolumn{2}{|l|}{ Child-Pugh score } \\
\hline Class A & $26(100 \%)$ \\
\hline Class B & $0(0 \%)$ \\
\hline \multicolumn{2}{|l|}{ Tumour size } \\
\hline$<3 \mathrm{~cm}$ & $19(73.07 \%)$ \\
\hline $3-5 \mathrm{~cm}$ & $7(26.93 \%)$ \\
\hline \multicolumn{2}{|l|}{ Tumour number } \\
\hline Single & $16(61.53 \%)$ \\
\hline $2-3$ & $11(38.47 \%)$ \\
\hline \multicolumn{2}{|l|}{ BCLC staging } \\
\hline Stage A & $18(69.23 \%)$ \\
\hline Stage B & 8 (30.77\%) \\
\hline \multicolumn{2}{|c|}{ Tumour differentiation } \\
\hline well & $9(34.61 \%)$ \\
\hline moderate & $10(38.46 \%)$ \\
\hline poorly & $7(26.92 \%)$ \\
\hline AFP & $545 \pm 892$ \\
\hline
\end{tabular}

Table 2 Concentration of the anticancer drugs

\begin{tabular}{llllll}
\hline Compounds & \multicolumn{4}{l}{ Concentration } \\
\cline { 2 - 6 } & $\mu \mathrm{g} / \mathrm{ml}$ & & & \\
\hline $5-\mathrm{PU}$ & 0.10 & 0.50 & 1.00 & 2.00 & 5.00 \\
PAC & 0.01 & 0.02 & 0.05 & 0.08 & 0.10 \\
CDDP & 0.10 & 0.20 & 0.50 & 1.00 & 2.00 \\
EPI & 0.01 & 0.05 & 0.10 & 0.50 & 1.00 \\
L-OHP & 0.10 & 0.50 & 1.00 & 2.00 & 5.00 \\
\hline
\end{tabular}

Applications of CD-DST in chemotherapeutic sensitivity examination have been demonstrated in human cancers, e.g., lung cancer, gastric cancer, breast cancer, or colorectal cancer [11-16]. However, reports focused on potential applications and efficacy of CD-DST in HCC remain rare $[17,18]$. This work aims to identify potential applications of CD-DST in HCC.

\section{Methods}

Cell lines and reagents

HepG2 (an HCC cell line) cells (Cat. 3111C0 001CCC000035) or HepG2/ADR (an HCC cell line resistant to Adriamycin), which were purchased from Cell Culture Center, Institute of Basic Medical Sciences, Chinese Academy of Medical Sciences, or descripted previously [8], were cultured in complete DMEM (Invitrogen, Carlsbad, CA, USA) in a sterile incubator maintained at $37{ }^{\circ} \mathrm{C}, 5 \%$ $\mathrm{CO}_{2}$. Anti-tumor agents, 5-furuolouracil (5-FU; Beijing Union Pharmaceutical Factory, China), Paclitaxel (PAC; Shanghai XudongHaipu Pharmaceutical CO., LTD., China), Cisplatin (CDDP; HaosohPharma, China), Epirubicin (EPI; Pfizer, USA), and Oxaliplatin (L-OHP; JiangshuHengrui Medicine CO, LTD, China) were purchased.

\section{Human tissue samples}

HCC specimens were obtained from surgical resections and preserved by our lab (from June 2015 and February 2016.). All patients with HBV (Hepatitis B Virus) - or HCV

Table 3 Growth rates of HepG2 cell in collagen gel droplets

\begin{tabular}{lllc}
\hline $\begin{array}{l}\text { Test } \\
\text { Batch }\end{array}$ & Baseline (0-time) & $\begin{array}{l}\text { Solvent Control } \\
\text { (6 days) }\end{array}$ & $\begin{array}{l}\text { Growth } \\
\text { rate (GR) }\end{array}$ \\
\hline 1 & O.D. $540 \mathrm{~nm}$ & 97.95 & 4.1 \\
& 22.18 & 92.33 & \\
25.45 & 95.47 & 4.56 \\
& 22.11 & 108.51 & \\
& 26.29 & 95.29 & 4.62 \\
& 23.48 & 106.31 & \\
& 18.21 & 111.03 & \\
& 19.83 & 114.15 & \\
& 23.21 & 110.76 & \\
\hline
\end{tabular}




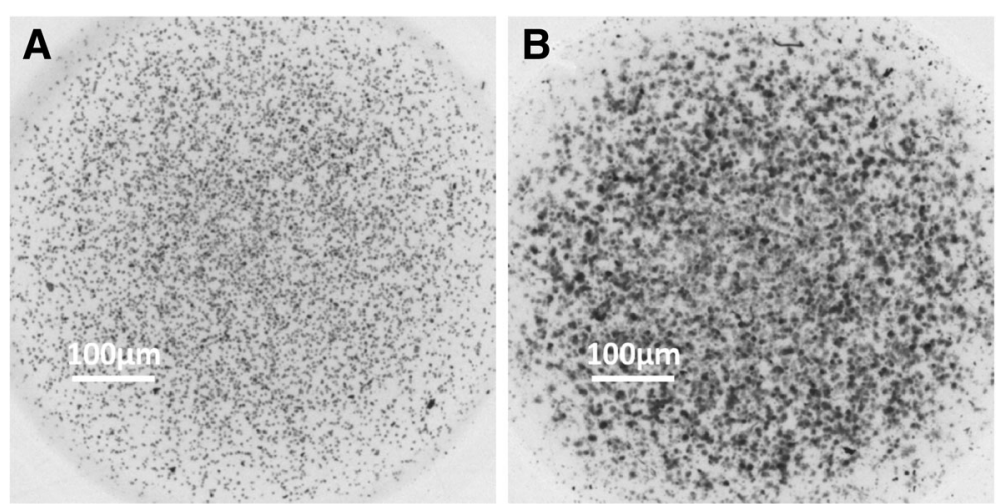

Fig. 1 HepG2 cell cultures in collagen gel droplets. HepG2 cells were seeded in collagen gel droplets and analyzed by a multifunctional microplate reader at $540 \mathrm{~nm}$. a The represent grey scale photograph of baseline (0-time) HepG2 cells; (b) The represent grey scale photograph of HepG2 cells after 5-7 days culturing

(Hepatitis C Virus) -related HCC, diagnosed based on an imaging examination confirmed by needle core biopsy, were included. Tumor stages were classified following the Barcelona Clinic Liver Cancer (BCLC) staging classification system $[19,20]$. The histological grades of HCC were identified based on Edmondson's grading system: welldifferentiated tumors, grade I or I-II; moderately differentiated tumors, grade II or II-III; and poorly differentiated umors, grade III or III-IV. Table 1 showed the clinical features of 26 patients.

\section{CD-DST}

collagen gel droplet embedded 3D-culture system (CDDST) was performed using a Kit Tumor Chemosensitivity Assay (Collagen gel Droplet culture method) provided by
Guangzhou Darui Biotechnology Co., Ltd. (Guangzhou, China), according to the manufacturer's instructions. For primary-culture cells of HCC, 0.2-0.5 g fresh-clinical specimens were digested by trypsin and incubated in collagen gel-coated flasks after eliminating blood cells or dead cells. Next, cells were collected and incubated in a collagen gel droplet embedded culture at $2 \times 10^{5}$ cells $/ \mathrm{ml}$ of collagen gel droplet ( $30 \mu \mathrm{l}$ per drop). Then, cells were treated with the indicted concentration of anticancer agents (Table 2) for $24 \mathrm{~h}$. After treatment with the anticancer agents, cells were incubated in a serum-free medium (4 ml PCM-2 medium to inhibit fibroblast proliferation) for 5-7 days to form colonies. Living cells were stained with neutral red, fixed with neutral formalin buffer, and directly examined/quantified by the cultured

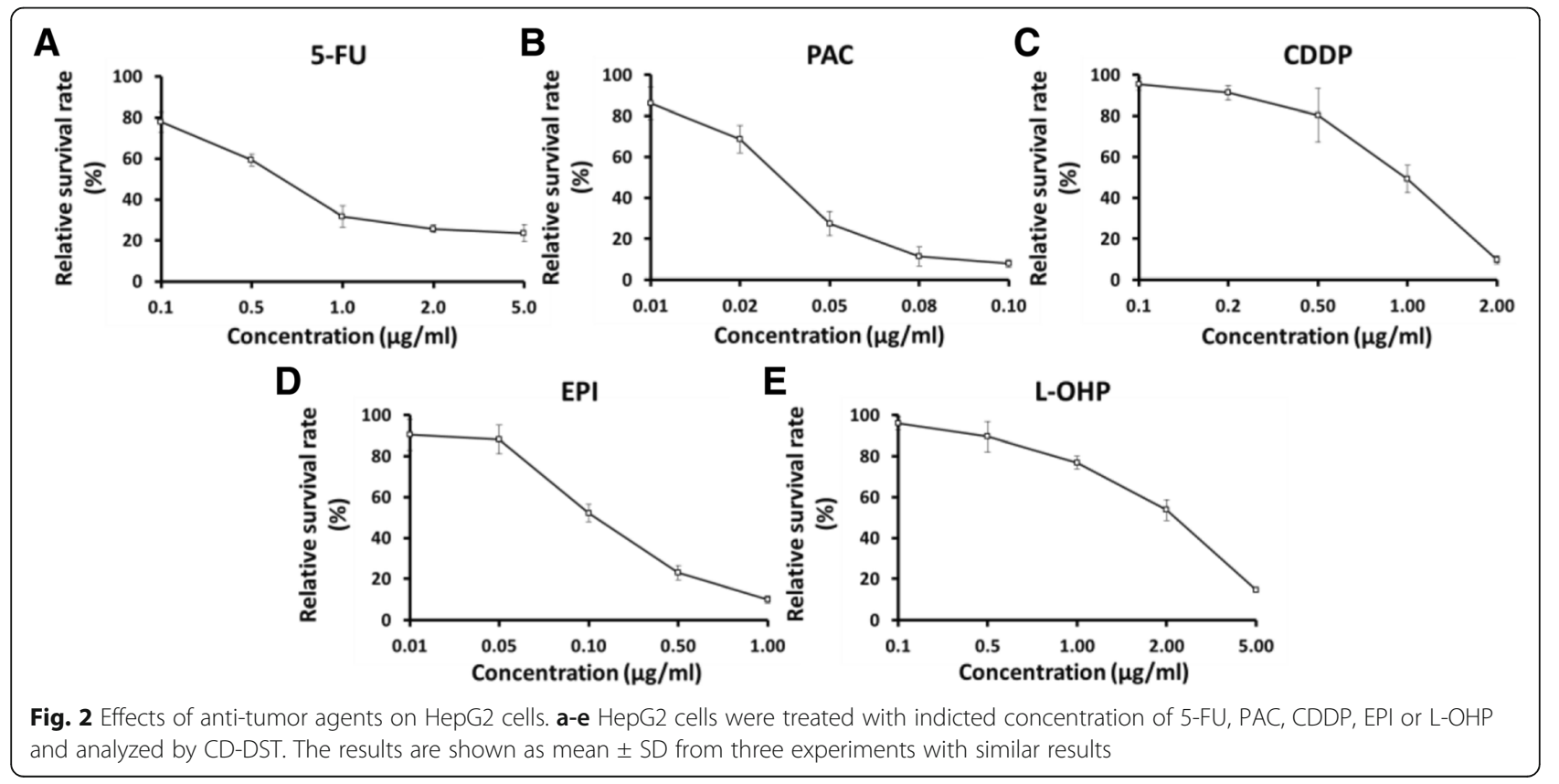



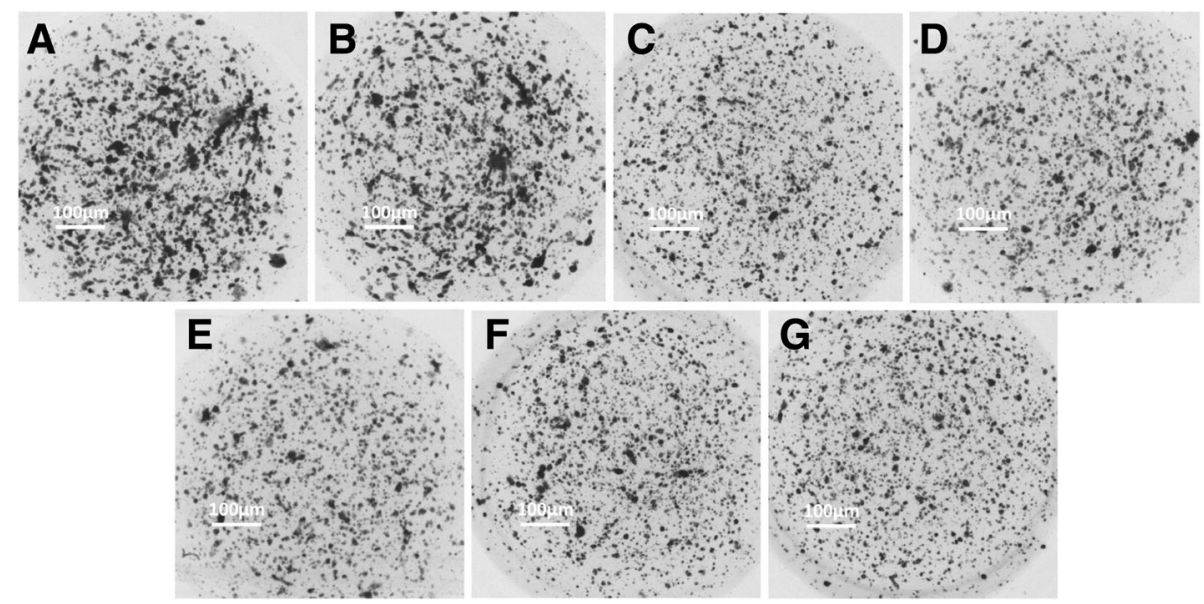

Fig. 3 The represent figures of $I C_{50}$ concentration anti-tumor agents on 3-D cultured HepG2 cells. a HepG2 cells were cultured in a 3-D manner. b-g HepG2 cells were treated with solvent control (b), or $\mathcal{K}_{50}$ concentration of agents, $0.8 \mu \mathrm{g} / \mathrm{ml} 5-\mathrm{FU}(\mathbf{c}), 0.3 \mu \mathrm{g} / \mathrm{ml}$ PAC (d), $1 \mu \mathrm{g} / \mathrm{ml}$ CDDP (e), $0.9 \mu \mathrm{g} / \mathrm{ml} \mathrm{EPI}(\mathbf{f})$ or $1.7 \mu \mathrm{g} / \mathrm{ml} \mathrm{L-OHP}(\mathbf{g})$

cells analysis system DR6690 (Guangzhou Darui Biotechnology Co., Ltd., China). The baseline (0-time group) of cells was indicated as the blank group. Inhibitory rates (IRs) were calculated as (O.D. $540 \mathrm{~nm}$ control group O.D. $540 \mathrm{~nm}$ administration group) / (O.D. $540 \mathrm{~nm}$ control group - O.D. $540 \mathrm{~nm}$ blank group) $\times 100 \%$. Relative survival rates $=100 \%-$ IR. For the cell line test $($ HepG2 cells), cells were harvested and analyzed using CD-DST tests. An IR value $>25 \%$ indicated that cells were sensitive to the compound.

\section{Statistical analyses}

Data are expressed as the mean \pm SD. Statistical analyses were performed using the paired t-test or Fisher's exact probability test. The $I C_{50}$ and $I C_{\max }$ values were calculated using Origin 8.5 software.

\section{Results}

HepG2 cell cultures in collagen gel droplets

To establish the CD-DST methods, HepG2 cells were cultured in collagen gel droplets. The O.D. $540 \mathrm{~nm}$ values were

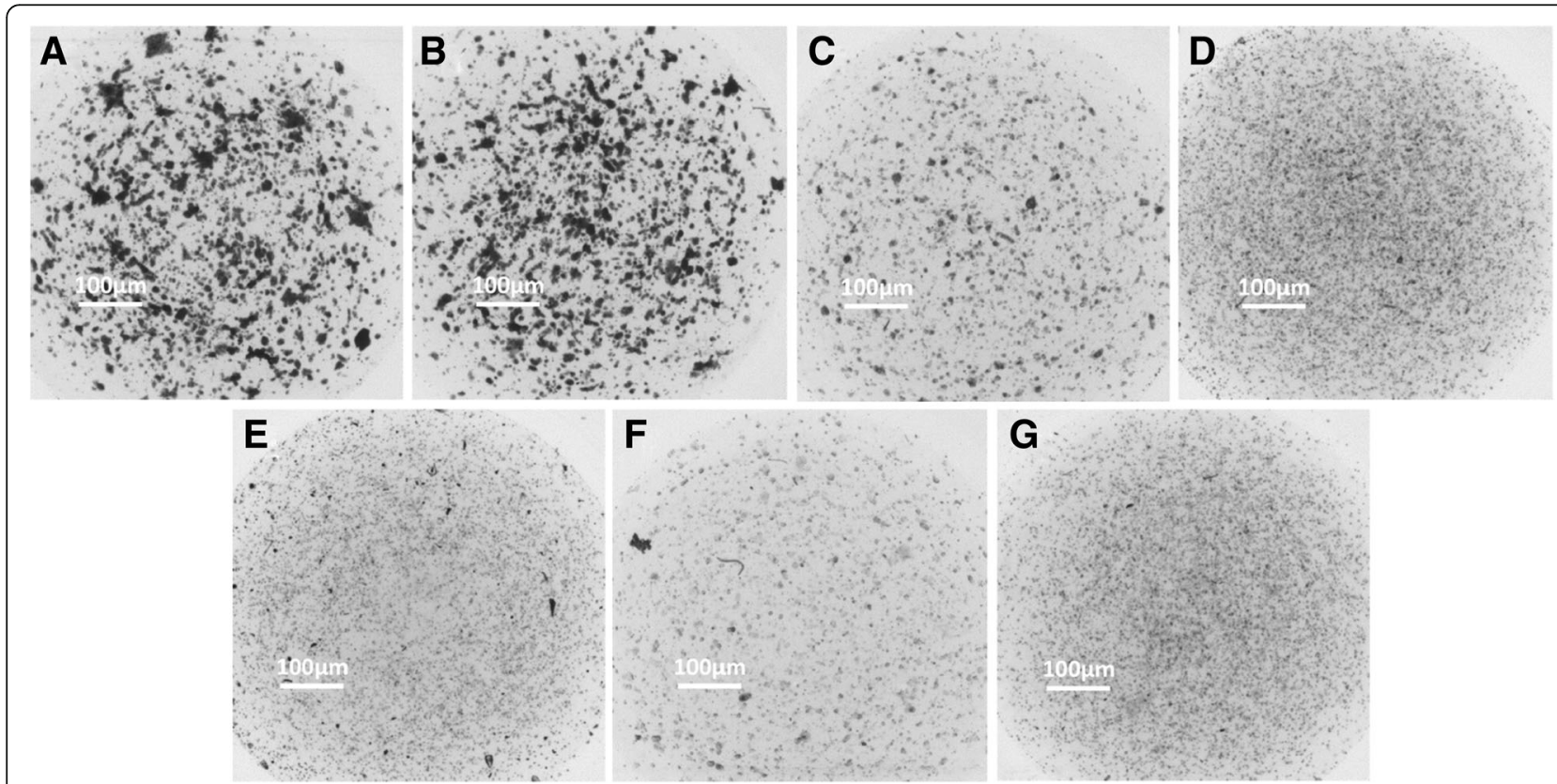

Fig. 4 The represent figures of $I C_{\max }$ concentration anti-tumor agents on 3-D cultured HepG2 cells. a HepG2 cells were cultured in a 3-D manner. $\mathbf{b}-\mathbf{g}$ HepG2 cells were treated with solvent control (b), or ICmax concentration of agents, $2.0 \mu \mathrm{g} / \mathrm{ml} 5-\mathrm{FU}(\mathbf{c}), 0.08 \mathrm{\mu g} / \mathrm{ml}$ PAC (d), $2.0 \mu \mathrm{g} / \mathrm{ml}$ CDDP (e), $0.5 \mu \mathrm{g} / \mathrm{ml}$ EPI (f) or $5.0 \mu \mathrm{g} / \mathrm{ml} \mathrm{L-OHP} \mathrm{(g)}$ 


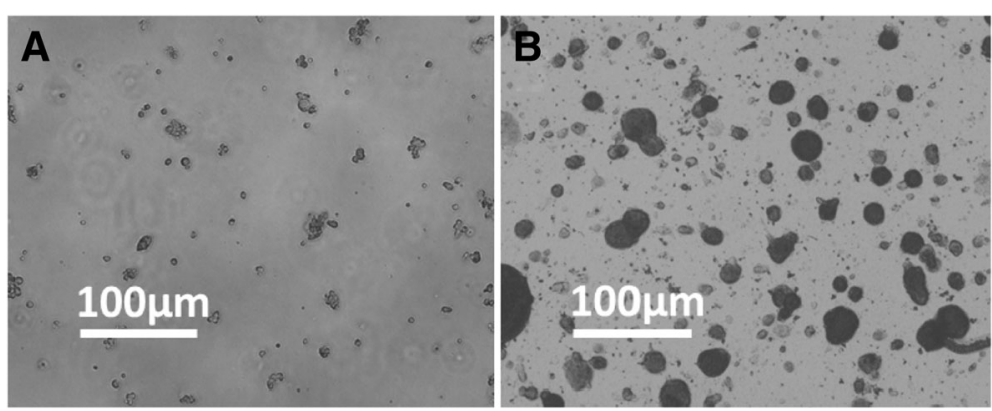

Fig. 5 Primary cells separated from clinical specimens culture in collagen gel droplets. Primary cells separated from clinical specimens were seeded in collagen gel droplets and analyzed by a multifunctional microplate reader at $540 \mathrm{~nm}$. a The represent grey scale photograph of baseline (0-time) cells; (b) The represent grey scale photograph of cells after 5-7 days culturing

examined at indicated time-points from three independent experiments. As shown in Table 3, similar results were obtained from each experiment, and the growth rates of HepG2 were from 4.1 to 4.62 -fold (Table 3). These results were further confirmed by representative photographs. As shown in Fig. 1, after 5-7 days' growth, the colony sizes were much larger than that at baseline.

\section{HepG2 cells are sensitive to anti-tumor agents}

Next, the effect of anti-tumor agents on HepG2 was detected by CD-DST (Fig. 2). The results showed that HepG2 was sensitive to 5-PU, PAC, CDDP, EPI, or L$\mathrm{OHP}$, and the $I C_{50}$ values were $0.83 \pm 0.45 \mu \mathrm{g} / \mathrm{ml}$, $0.03 \pm 0.02 \mu \mathrm{g} / \mathrm{ml}, 1.15 \pm 0.75 \mu \mathrm{g} / \mathrm{ml}, 0.09 \pm 0.03 \mu \mathrm{g} / \mathrm{ml}$, and $1.76 \pm 0.44 \mu \mathrm{g} / \mathrm{ml}$, respectively. Moreover, the $I C_{\max }$ values were $2.0 \mu \mathrm{g} / \mathrm{ml}, 0.08 \mu \mathrm{g} / \mathrm{ml}, 2.0 \mu \mathrm{g} / \mathrm{ml}, 0.5 \mu \mathrm{g} / \mathrm{ml}$, and $5.0 \mu \mathrm{g} / \mathrm{ml}$, respectively. The representative photographs are shown in Figs. 3 and 4.

\section{Sensitivity of primary cells separated from HCC clinical specimens}

Next, the sensitivity of primary cells separated from HCC clinical specimens to anti-tumor agents was detected by CD-DST methods (Fig. 5). Cells were treated with an $I C_{\max }$ or $I C_{50}$ concentration of antitumor agents. As shown in Table 4, 8/26, 9/26, and 5/26 patients may be sensitive to $I C_{\max }$ values of CDDP, EPI, or L-OHP, and only $3 / 26,4 / 26$, and $2 / 26$ patients may be sensitive to $I C_{50}$. However, no patients were sensitive to 5 -Fu or

Table 4 the sensitivity of patients to anti-tumor agents

\begin{tabular}{llll}
\hline Compounds & $\begin{array}{l}\text { Total } \\
\text { patients }\end{array}$ & \multicolumn{2}{l}{ Patients were sensitive to compounds } \\
\cline { 3 - 4 } & 26 & - & $I_{\text {max }}$ group \\
\hline 5-FU & 26 & - & - \\
PAC & 26 & 8 & - \\
CDDP & 26 & 9 & 3 \\
EPI & 26 & 5 & 4 \\
L-OHP & 26 & & 2 \\
\hline
\end{tabular}

PAC. The represent photographs are shown in Fig. 6. The characteristics of the tumor (histological grade, BCLC grade number of nodules) in relation to the sensitivity to chemotherapeutic agents are shown in Table 5. Taken together, patients suffering from HCC were not sensitive to PAC or 5-Fu, and only a few obtained clinical benefits from CDDP, EPI, or L-OHP.

\section{2-D cultured HepG2 cells were more sensitive to anti-tumor agents}

Moreover, to confirm the sensitivity of HCC cells to anti-tumor agents, the effect of agents on HepG2 or HepG2/ADR, an MDR cell line, was examined by MTT assays and the $I C_{50} / I C_{\max }$ concentrations were calculated. The results are shown in Table 6. The $I C_{50}$ value of agents on HpeG2 cells obtained from the MTT assays were much lower than those obtained from CD-DST. Moreover, the $I C_{50}$ value of agents on HpeG2/ADR cells obtained from the MTT assays were similar with those obtained from CD-DST. These results indicated that sensitivity of 2-D cultured HepG2 cells to anti-tumor agents was much higher than that in 3-D-cultured HepG2 cells.

\section{Discussion}

$\mathrm{HCC}$ is currently one of the most common malignancies, especially in China and the Asia-Pacific region. Although an oral multi-targeted kinase inhibitor, sorafenib, has been used as a curative approach, cytotoxicity chemotherapeutic agents are still treatment choices, e.g., oral medication or hepatic artery chemotherapy and transcatheter arterial chemoembolization (TACE) [2125]. 5-FU, CDDP, EPI, and L-OHP can induce double DNA strand breaking (DSB) and block DNA replication via multi-mechanisms [26]. PAC targets microtubules and disrupts cell division [27]. It is well known that HCC may be resistant to almost all kinds of cytotoxicity chemotherapeutic agents due to its multi-drug resistance (MDR) features. During the MDR process, breast cancer 


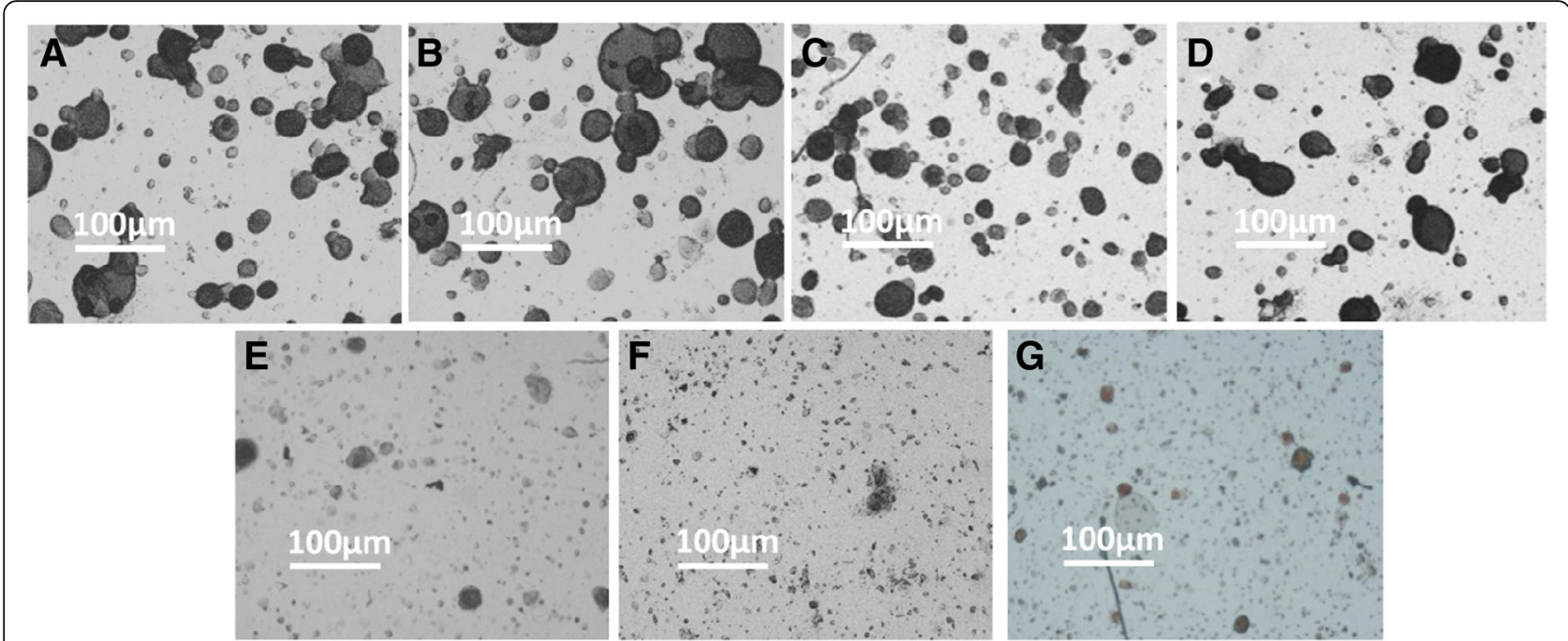

Fig. 6 The represent figures of patients are sensitive to $I C_{\max }$ concentration anti-tumor agents. a Primary cells separated from clinical specimens were cultured in a 3-D manner. b-g Primary HCC cells were treated with solvent control (b), or ICmax concentration of agents, $2.0 \mathrm{\mu g} / \mathrm{ml} 5-\mathrm{FU}(\mathbf{c})$, $0.08 \mu \mathrm{g} / \mathrm{ml} \mathrm{PAC}(\mathbf{d}), 2.0 \mu \mathrm{g} / \mathrm{ml} \operatorname{CDDP}(\mathbf{e}), 0.5 \mu \mathrm{g} / \mathrm{ml}$ EPI (f) or $5.0 \mu \mathrm{g} / \mathrm{ml} \mathrm{L-OHP}(\mathbf{g})$

resistance protein $(\mathrm{BCRP})$, multi-drug resistance relative protein2/3 (MRP2/3) or multi-drug resistance 1 (MDR-1) may participate in the un-anticipated efficacy loss of chemotherapeutic agents via the phase I or phase II drug metabolizing process [28]. Some other signaling pathways, e.g. JAK/STAT (janus kinase / signal transducers and activators of transcription), PI3K/mTOR (phosphatidylinositol 3-kinase / mammalian target of rapamycin) or hypoxiarelated pathways, would also participate in the MDR of HCC $[29,30]$.

Moreover, a higher level of these resistance genes has been confirmed in HCC/liver clinical specimens than that in HCC cell lines. Tumor cells in solid tumors grow in a 3-D pattern. Therefore, it is urgent to establish an in vitro model reflecting the 3-D culture of tumor cells. To date, there is no effective or rapid testing system for screening sensitive drugs for
HCC patients to guide the clinical individual chemotherapy. For the first time, our presence work establishes the application of CD-DST in HCC chemotherapeuticefficacy examination. The sensitivity of HepG2 or primary cells separated from $\mathrm{HCC}$ clinical specimens to 5-FU, PAC, CDDP, EPI, and L-OHP was identified. No patients were sensitive to PAC or 5-FU. As shown in Table 5, the characteristics of the tumors (histological grade, BCLC grade number of nodules) in relation to their sensitivity to chemotherapeutic agents were identified. Patients with BCLC $A$ or well-differentiated HCC would more sensitive to CDDP or L-OHP, whereas patients with BCLC B or moderate-differentiation $\mathrm{HCC}$ would be more sensitive to EPI than CDDP or L-OHP. Moreover, patients with poordifferentiation HCC would not be sensitive to anti-tumor agents, and the tumor numbers seemed unrelated to antitumor agent sensitivity.

Table $\mathbf{5}$ characteristics of the tumor in relation to sensitivity to chemotherapeutic agents

\begin{tabular}{|c|c|c|c|c|c|c|c|c|c|c|c|}
\hline \multicolumn{2}{|c|}{ Compounds } & \multirow{3}{*}{$\begin{array}{l}\text { Sensitive } \\
\text { patients }\end{array}$} & \multicolumn{2}{|c|}{$\mathrm{BCLC}$} & \multicolumn{2}{|c|}{ Child-Pugh } & \multicolumn{2}{|c|}{ Tumor Number } & \multicolumn{3}{|c|}{ Tumor differentiation } \\
\hline & & & \multirow{2}{*}{$\frac{A}{6}$} & \multirow{2}{*}{$\frac{B}{2}$} & \multirow{2}{*}{$\frac{A}{8}$} & \multirow{2}{*}{$\begin{array}{l}\mathrm{B} \\
-\end{array}$} & \multirow{2}{*}{$\begin{array}{l}\text { Single } \\
5\end{array}$} & \multirow{2}{*}{$\frac{2 \sim 3}{3}$} & \multirow{2}{*}{$\begin{array}{l}\text { Well } \\
7\end{array}$} & \multirow{2}{*}{$\begin{array}{l}\text { moderate } \\
1\end{array}$} & \multirow{2}{*}{$\frac{\text { poorly }}{-}$} \\
\hline CDDP & $I_{\max }$ & & & & & & & & & & \\
\hline & $\mathcal{I}_{50}$ & 3 & 3 & - & 3 & - & 2 & 1 & 3 & - & - \\
\hline \multirow[t]{2}{*}{ EPI } & $I_{\max }$ & 9 & 5 & 4 & 9 & - & 6 & 3 & 4 & 5 & - \\
\hline & $\mathcal{C}_{50}$ & 4 & 3 & 1 & 4 & - & 2 & 2 & 2 & 2 & - \\
\hline \multirow[t]{2}{*}{$\mathrm{L}-\mathrm{OHP}$} & $I_{\max }$ & 5 & 5 & - & 5 & - & 3 & 2 & 5 & 1 & - \\
\hline & $\mathcal{C}_{50}$ & 2 & 2 & - & 2 & - & 1 & 1 & 2 & - & - \\
\hline \multirow[t]{2}{*}{ 5-FU } & $I_{\max }$ & - & - & - & - & - & - & - & - & - & - \\
\hline & $\mathcal{K}_{50}$ & - & - & - & - & - & - & - & - & - & - \\
\hline \multirow[t]{2}{*}{ PAC } & $I_{\max }$ & - & - & - & - & - & - & - & - & - & - \\
\hline & $I_{50}$ & - & - & - & - & - & - & - & - & - & - \\
\hline
\end{tabular}


Table 6 the sensitivity of HepG2 or HepG2/ADR cells to antitumor agents

\begin{tabular}{|c|c|c|c|}
\hline \multirow[t]{2}{*}{ Compounds } & 2-D HepG2 & 2-D HepG2/ADR & \multirow[t]{2}{*}{ 3-D HepG2 } \\
\hline & \multicolumn{2}{|c|}{$\mathcal{C}_{50}$ values $(\mu \mathrm{g} / \mathrm{ml})$} & \\
\hline 5-PU & $0.45 \pm 0.06$ & $0.77 \pm 0.33$ & $0.83 \pm 0.45$ \\
\hline PAC & $0.01 \pm 0.00$ & $0.02 \pm 0.01$ & $0.03 \pm 0.02$ \\
\hline CDDP & $0.26 \pm 0.23$ & $1.39 \pm 0.40$ & $1.15 \pm 0.75$ \\
\hline EPI & $0.02 \pm 0.01$ & $0.16 \pm 0.04$ & $0.09 \pm 0.03$ \\
\hline L-OHP & $0.55 \pm 0.12$ & $1.85 \pm 0.44$ & $1.76 \pm 0.44$ \\
\hline
\end{tabular}

Traditionally, the biological behavior of cancer cells was determined using 2-D methods, e.g., MTT or colony formation. However, 2-D methods may be insufficient to reflect the in vivo behavior of cancer cells in solid tumor tissues [7]. Thus, it is valuable to develop and validate a rapid method to examine the biological behavior of cancer cells in a 3-D manner. Tissue engineering research, e.g., 3-D spatial array, investigated the involvement of the extracellular matrix (ECM) in solid tissues [7]. The interaction between cells and the ECM modulates the behavior and features of solid tumors [8-10]. Collagen is a main constituent of the ECM and supports the formation of the microenvironment in solid tumors [8-12]. CD-DST is a mature test in which primary-culture cells of HCC are separated from surgical resection specimens embedded in collagen droplets [7-12]. Applications of CD-DST in chemotherapeutic sensitivity examination have been demonstrated in some kinds of human cancers, e.g., lung cancer, gastric cancer, breast cancer, and colorectal cancer [8-12]. Higashiyama et al. (2010) predicted the chemotherapeutic effect on postoperative recurrence in non-small cell lung cancer patients [9]. Sun et al. (2013) established a 3-D gastric tumor culture model [10]. Lin et al. (2015) revealed the effect of pyruvate kinase M2 on Epirubicin and 5-Fluorouracil in breast cancer by CD-DST [11]. Takahashi et al. (2015) examined the anti-tumor activity of fucoxanthin and fucoxanthinol on cell lines or primary cells from colorectal cancer clinical specimens [12]. In the present work, for the first time, we developed and validated an effective method to predict the resistance of HCC patients to anti-tumor agents. The result showed that 2-D cultured HepG2 cells were more sensitive to anti-tumor agents than cells cultured in a 3-D manner but similar to a 2-D cultured resistance cell line, HepG2/ADR. Moreover, primary cells separated from clinical specimens were much more resistant to anti-tumor agents. Therefore, CT-DST, a 3-D tumor model, is valuable for evaluating and mimicking the in vivo efficacy of antitumor agents.

\section{Conclusions}

The in vitro drug sensitivity exanimation validated the MDR features of HCC. CD-DST may be a useful method to predict the potential clinical benefits of anticancer agents for HCC patients.

\section{Abbreviations \\ 5-FU: 5-furuolouracil; BCRP: Breast cancer resistance protein; CDDP: Cisplatin; CD-DST: Collagen gel droplet embedded 3D-culture system; EPI: Epirubicin; HCC: Hepatocellular carcinoma; IR: Inhibitory rate; JAK: Janus kinase; L- OHP: Oxaliplatin; MDR: Multi-drug resistance; MDR-1: Multi-drug resistance 1; MRP2/3: Multi-drugs resistance relative protein2/3; mTOR: Mammalian target of rapamycin; PAC: Paclitaxel; PI3K: Phosphatidylinositol 3-kinase; STAT: Signal transducers and activators of transcription; TACE: Transcatheter arterial chemoembolization}

\section{Acknowledgements}

We thank Dr. Juan-juan Zhao for her advice and excellent technical assistances to this study.

\section{Funding}

This work was supported by direct grants from the Chinese Government: the Dean Innovation Fund (YNKT2014039) from the 302nd Hospital of Chinese PLA, Beijing 100,039, People's Republic of China. These funding sources or funding bodies had no role in the design of this study and will not have any role during its execution, analyses, interpretation of the data, or decision to submit the results.

\section{Availability of data and materials}

Additional data and materials may be requested from the corresponding author on reasonable request.

\section{Open access}

This article is distributed under the terms of the Creative Commons Attribution 4.0 International License (http://creativecommons.org/licenses/by/ 4.0), which permits unrestricted use, distribution, and reproduction in any medium, provided you give appropriate credit to the original author(s) and the source, provide a link to the Creative Commons license, and indicate if changes were made. The Creative Commons Public Domain Dedication waiver (http://creativecommons.org/publicdomain/zero/1.0) applies to the data made available in this article, unless otherwise stated.

\section{Authors' contributions}

ZXH, JFB and ZZ made substantial contributions to conception and design. $J H, Z X H, F F$, YTC. YKZ QYJ, SQW, and YH made substantial contributions to acquisition of data, or analysis and interpretation of data. JH, FF and ZZ have been involved in drafting the manuscript or revising it critically for important intellectual content. YSW, XNG, QC and YW have given final approval of the version to be published. Each author should have participated sufficiently in the work to take public responsibility for appropriate portions of the content; and agreed to be accountable for all aspects of the work in ensuring that questions related to the accuracy or integrity of any part of the work are appropriately investigated and resolved. All authors read and approved the final manuscript.

\section{Ethics approval and consent to participate}

Our studies are in compliance with the Helsinki Declaration. The collection of tissues and the study protocol were approved by the Ethics Committee of No. 302 Military Hospital of China, with informed written and verbal consent from 26 patients. The methods did not relate to the clinical trial or methods.

Consent for publication

Not applicable

\section{Competing interests}

The authors declare that they have no competing interests. Author Xunian Gao works at/is employed by Guangzhou Darui Biotechnology as the supplier of the chemosensitivity assay for this research.

\section{Publisher's Note}

Springer Nature remains neutral with regard to jurisdictional claims in published maps and institutional affiliations. 


\section{Author details}

'Research Center for Clinical and Translational Medicine, the 302nd Hospital of Chinese PLA, Beijing 100039, People's Republic of China. ${ }^{2}$ Department of Hepatobiliary Surgery, the 302nd Hospital of Chinese PLA, Beijing 100039, People's Republic of China. ${ }^{3}$ School of Laboratory Medicine and Biotechnology, Southern Medical University, Guangzhou 510515, People's Republic of China. ${ }^{4}$ Research Institute, Guangzhou Darui Biotechnology Co Ltd, Guangzhou 510515, People's Republic of China.

Received: 8 November 2016 Accepted: 26 October 2017

Published online: 08 November 2017

\section{References}

1. Wang $C$, Wang $H$, Yang W, Hu K, Xie H, Hu KQ, Bai W, Dong Z, Lu Y, Zeng Z, Lou M, Wang H, Gao X, Chang X, An L, Qu J, Li J, Yang Y. Multicenter randomized controlled trial of percutaneous cryoablation versus radiofrequency ablation in hepatocellular carcinoma. Hepatology. 2015:61:1579-90.

2. Wang FS, Fan JG, Zhang Z, Gao B, Wang HY. The global burden of liver disease: the major impact of China. Hepatology. 2014;60:2099-108.

3. Tang R, Liu H, Yuan Y, Xie K, Xu P, Liu X, Wen J. Genetic factors associated with risk of metabolic syndrome and hepatocellular carcinoma. Oncotarget. 2017;8:35403-11.

4. He G, Dhar D, Nakagawa H, Font-Burgada J, Ogata H, Jiang Y, Shalapour S, Seki E, Yost SE, Jepsen K, Frazer KA, Harismendy O, Hatziapostolou M, Iliopoulos D, Suetsugu A, Hoffman RM, Tateishi R, Koike K, Karin M. Identification of liver cancer progenitors whose malignant progression depends on autocrine IL-6 signaling. Cell. 2013;155:384-96.

5. Chen W, Zheng R, Baade PD, Zhang S, Zeng H, Bray F, Jemal A, Yu XQ, He J. Cancer statistics in China 2015. CA Cancer J Clin. 2016;66:115-32.

6. Jeong S, Cheng Q, Huang L, Wang J, Sha M, Tong Y, Xia L, Han L, Xi Z, Zhang J, Kong X, Gu J, Xia Q. Risk stratification system to predict recurrence of intrahepatic cholangiocarcinoma after hepatic resection. BMC Cancer. 2017;17:464

7. Yang S, Wang XQ. XLF-mediated NHEJ activity in hepatocellular carcinoma therapy resistance. BMC Cancer. 2017;17:344

8. Jia $H$, Yang $Q$, Wang $T$, Cao $Y$, Jiang QY, Ma HD, Sun HW, Hou MX, Yang YP, Feng F. Rhamnetin induces sensitization of hepatocellular carcinoma cells to a small molecular kinase inhibitor or chemotherapeutic agents. Biochim Biophys Acta. 1860;2016:1417-30.

9. Geschwind JF, Gholam PM, Goldenberg A, Mantry P, Martin RC, Piperdi B, Zigmont E, Imperial J, Babajanyan S, Foreman PK, Cohn A. Use of Transarterial Chemoembolization (TACE) and Sorafenib in patients with Unresectable Hepatocellular carcinoma: US regional analysis of the GIDEON registry. Liver Cancer. 2016;5:37-46.

10. Chen Y, Feng F, Gao X, Wang C, Sun H, Zhang C, Zeng Z, Lu Y, An L, Qu J, Wang $F$, Yang $Y$. MiRNA153 reduces effects of chemotherapeutic agents or small molecular Kinase inhibitor in HCC cells. Curr Cancer Drug Targets. 2015;15:176-87.

11. Takamura Y, Kobayashi H, Taguchi T, Motomura K, Inaji H, Noguchi S. Prediction of chemotherapeutic response by collagen gel droplet embedded culture-drug sensitivity test in human breast cancers. Int J Cancer. 2002;98(3):450-5

12. Miyazaki R, Anayama T, Hirohashi K, Okada H, Kume M, Orihashi K. In vitro drug sensitivity tests to predict molecular target drug responses in surgically Resected lung cancer. PLoS One. 2016;11:e0152665.

13. Higashiyama M, Oda K, Okami J, Maeda J, Kodama K, Imamura F, Minamikawa K, Takano T, Kobayashi H. Prediction of chemotherapeutic effect on postoperative recurrence by in vitro anticancer drug sensitivity testing in non-small cell lung cancer patients. Lung Cancer. 2010;68:472-7.

14. Sun $P, X u Y, D \cup X$, Ning N, Sun H, Liang W, Li R. An engineered threedimensional gastric tumor culture model for evaluating the antitumor activity of immune cells in vitro. Oncol Lett. 2013;5:489-94.

15. Lin Y, Lv F, Liu F, Guo X, Fan Y, Gu F, Gu J, Fu L. High expression of Pyruvate Kinase $M 2$ is associated with Chemosensitivity to Epirubicin and 5-fluorouracil in breast cancer. J Cancer. 2015;6:1130-9.

16. Takahashi K, Hosokawa M, Kasajima H, Hatanaka K, Kudo K, Shimoyama N, Miyashita K. Anticancer effects of fucoxanthin and fucoxanthinol on colorectal cancer cell lines and colorectal cancer tissues. Oncol Lett. 2015;10:1463-7.
17. Yoshioka $Y$, Tsutsumi $Y$, Kamada H, Kihira T, Tsunoda S, Yamamoto $Y$, Okamoto T, Shibata H, Mukai Y, Taniai M, Shimizu T, Kawamura M, Abe Y, Nakagawa S, Mayumi T. Selective enhancer of tumor vascular permeability for optimization of cancer chemotherapy. Biol Pharm Bull. 2004:27:437-9.

18. Shrum B, Costello P, McDonald W, Howlett C, Donnelly M, McAlister VC. In vitro three dimensional culture of hepatocellular carcinoma to measure prognosis and responsiveness to chemotherapeutic agents. Hepatobiliary Surg Nutr. 2016;5:204-8.

19. Zhu M, Li M, Wang T, Linghu E, Wu B. MicroRNA-137 represses FBI-1 to inhibit proliferation and in vitro invasion and migration of hepatocellular carcinoma cells. Tumour Biol. 2016:37:13995-4008.

20. Zhong JH, Peng NF, You XM, Ma L, Xiang X, Wang YY, Gong WF, Wu FX, Xiang BD, Li L. Tumor stage and primary treatment of hepatocellular carcinoma at a large tertiary hospital in China: a real-world study. Oncotarget. 2017:8:18296-302

21. Liu F, Wang G, Wang X, Che Z, Dong W, Guo X, Wang Z, Chen P, Hou D, Zhang Q, Zhang W, Pan Y, Yang D, Liu H. Targeting high aurora kinases expression as an innovative therapy for hepatocellular carcinoma. Oncotarget. 2017:8:27953-65.

22. Cheng Y, Luo R, Zheng H, Wang B, Liu Y, Liu D, Chen J, Xu W, Li A, Zhu Y. Synergistic anti-tumor efficacy of sorafenib and fluvastatin in hepatocellular carcinoma. Oncotarget. 2017:8:23265-76.

23. Tong Y, Li Z, Liang Y, Yu H, Liang X, Liu H, Cai X. Postoperative adjuvant TACE for patients of hepatocellular carcinoma in AJCC stage I: friend or foe? A propensity score analysis. Oncotarget. 2017;8:26671-8.

24. Kobayashi H, Tanisaka K, Doi O, Kodama K, Higashiyama M, Nakagawa H, Miyake M, Taki T, Hara S, Yasutomi M, Hanatani Y, Kotake K, Kubota T. An in vitro chemosensitivity test for solid human tumors using collagen gel droplet embedded cultures. Int J Oncol. 1997;11(3):449-55.

25. Zeng Z, Ren J, O'Neil M, Zhao J, Bridges B, Cox J, Abdulkarim B, Schmitt TM Kumer SC, Weinman SA. Impact of stem cell marker expression on recurrence of TACE-treated hepatocellular carcinoma post liver transplantation. BMC Cancer. 2012;12:584.

26. Terazawa T, Kondo S, Hosoi H, Morizane C, Shimizu S, Mitsunaga S, Ikeda M, Ueno H, Okusaka T. Transarterial infusion chemotherapy with cisplatin plus S-1 for hepatocellular carcinoma treatment: a phase I trial. BMC Cancer. 2014:14:301.

27. Zhu M, Li W, Lu Y, Dong X, Chen Y, Lin B, Xie X, Guo J, Li M. Alpha fetoprotein antagonizes apoptosis induced by paclitaxel in hepatoma cells in vitro. Sci Rep. 2016;6:26472.

28. Zhao J, Bai Z, Feng F, Song E, Du F, Zhao J, Shen G, Ji F, Li G, Ma X, Hang X, Xu B. Cross-talk between EPAS-1/HIF-2a and PXR signaling pathway regulates multi-drug resistance of stomach cancer cell. Int J Biochem Cell Biol. 2016:72:73-88.

29. Cerezo D, Ruiz-Alcaraz AJ, Lencina-Guardiola M, Cánovas M, GarcíaPeñarrubia P, Martínez-López I, Martín-Orozco E. Attenuated JNK signaling in multidrug-resistant leukemic cells. Dual role of MAPK in cell survival. Cell Signal. 2017;30:162-70.

30. Zhu YJ, Zheng B, Wang HY, Chen L. New knowledge of the mechanisms of sorafenib resistance in liver cancer. Acta Pharmacol Sin. 2017:38:614-22. 